Rahayu, A.Y. • T.A.D. Haryanto · S. N. Iftitah

\title{
Pertumbuhan dan hasil padi gogo hubungannya dengan kandungan prolin dan 2-acetyl-1-pyrroline pada kondisi kadar air tanah berbeda
}

\author{
Growth and yield of aromatic upland rice related to proline and \\ 2-acetyl-1-pyrroline content at different soil water content
}

Diterima : 15 November 2016/Disetujui : 15 Desember 2016 / Dipublikasikan : 30 Desember 2016

CDepartment of Crop Science, Padjadjaran University

\begin{abstract}
The objectives of this study was to know the responses of upland rice under different soil water content on growth and yield, and proline and 2-acetyl-1-pyrroline contents. The experiment was conducted in Tidar Magelang University from September 2012 to March 2013. Randomized Complete Block Design with factors of upland rice variety viz. Inpago Unsoed-1, JSPGA 136, Situbagendit and Mentik Wangi, and different soil water content viz. $100 \%$ of field capacity and $50 \%$ of field capacity were tested. The observed variables were plant height $(\mathrm{cm})$, total number of tillers (stems), number of productive tillers (stems), total root length $(\mathrm{m})$, flowering time (day), harvest time (day), length of panicle $(\mathrm{cm})$, number of grain per panicle, 1000 grain weight $(\mathrm{g})$, grain weight per hill $(\mathrm{g})$, proline content $(\mu$ $\mathrm{M} / \mathrm{g}$ ) and 2-acetyl-1-pyrroline content (ppm). In general, at $50 \%$ field capacity plant growth and yield upland rice were low but it was high results on proline and 2-acetyl-1-pyrroline contents. The experiment showed that Mentik wangi variety had the high results on plant growth and yield and contents of proline and 2acetyl-1-pyrroline at $50 \%$ field capacity of soil water content.
\end{abstract}

Keywords: Upland rice - Soil water content . Plant growth · Yield · Proline · 2-acetyl-1pyrroline

\footnotetext{
Dikomunikasikan oleh Sakhidin

Rahayu, A.Y. ${ }^{1}$ T.A.D. Haryanto ${ }^{2}$ S. N. Iftitah ${ }^{3}$

1) Laboratorium Agroekologi, Program Studi

Agroteknologi, Fakultas Pertanian Unsoed

Jln. Dr. Soeparno, Karangwangkal, Purwokerto 53123

2) Lab. Pemuliaan Tanaman, Program Studi Agroteknologi,

Fakultas Pertanian Unsoed,

3) Program Studi Agroteknologi, Fakultas Pertanian,

Universitas Tidar, Jl. Kapten Suparman 39 Magelang

Korespondensi e-mail: nurul.untidar@gmail.com
}

Sari Penelitian ini bertujuan untuk mengetahui respons varietas padi gogo pada kadar air tanah berbeda terhadap pertumbuhan, hasil dan kandungan prolin dan 2-acetyl-1-pyrroline biji. Penelitian dilaksanakan di Universitas Tidar Magelang mulai bulan September 2012 sampai dengan Maret 2013. Percobaan menggunakan Rancangan Acak Kelompok Lengkap terdiri atas dua faktor yaitu varietas padi gogo (Inpago Unsoed-1, galur JSPGA 136, varietas Situ-bagendit (non-aromatik) dan varietas Mentik Wangi) dan tingkat kadar air tanah (100\% kapasitas lapang dan $50 \%$ kapasitas lapang). Variabel pengamatan meliputi: tinggi tanaman (cm), jumlah anakan total per rumpun (batang), jumlah anakan produktif (batang), total panjang akar (m), umur berbunga (hst), umur panen (hst), panjang malai $(\mathrm{cm})$, jumlah bulir per malai, bobot 1000 biji (g), bobot biji per rumpun $(\mathrm{g})$, kandungan prolin $(\mu \mathrm{M} / \mathrm{g})$ dan kandungan 2-acetyl-1-pyrroline (ppm). Secara umu padi gogo yang ditanam pada kondisi kadar air tanah $50 \%$ kapasitas lapang menghasilkan umur panen panjang dengan pertumbuhan dan hasil rendah namun memiliki kandungan prolin dan kandungan 2-acetyl-1-pyrroline lebih tinggi dibandingkan dengan yang ditanam pada kondisi kadar air tanah $100 \%$ kapasitas lapang. Namun demikian, pada kondisi kadar air tanah $50 \%$ kapasitas lapang, varietas Mentik Wangi menunjukan hasil tinggi pada karakter pertumbuhan dan hasil serta kandungan 2-acetyl1-pyrroline dan kandungan prolin.

Kata kunci: Padi gogo $\cdot$ Kadar air tanah .

Pertumbuhan · Hasil · Prolin · 2-acetyl-1-pyrroline

\section{Pendahuluan}

Komoditas pangan yang dapat dibudidayakan di lahan kering dalam mengoptimalkan ekstensifikasi pertanian guna menunjang 
ketahanan pangan adalah padi gogo aromatik. Padi gogo aromatik berpotensi untuk dikembangkan sebagai salah satu usaha peningkatan produksi beras nasional dalam rangka menunjang ketahanan pangan, karena produksinya cukup tinggi yaitu antara 3,6-5,6 ton/ha. Selain itu padi gogo aromatik mempunyai beberapa keunggulan dibandingkan padi gogo pada umumnya diantaranya rasa nasi pulen, produksi tinggi dan aromatik (Yuwandha, 2008).

Pada lahan kering sering terjadi kekeringan karena pengairan pada lahan kering mengandalkan curah hujan. Oleh karena itu, pada saat musim kemarau atau tidak turun hujan seringkali tanaman padi gogo mengalami cekaman kekeringan. Cekaman kekeringan menyebabkan pertumbuhan dan produksi tanaman terganggu. Pengaruh cekaman air terhadap pertumbuhan tanaman tergantung pada tingkat cekaman yang dialami dan jenis atau genotipe yang ditanam. Pengaruh awal dari tanaman yang mendapat cekaman air adalah terjadinya hambatan terhadap pembukaan stomata daun yang kemudian berpengaruh besar terhadap proses fisiologis dan metabolisme dalam tanaman. Salisbury dan Ross (1995) menyatakan bahwa stres kekeringan akan menyebabkan menurunnya fotosintesis, respirasi, meningkatnya penutupan stomata, sintesis ABA, pembesaran dan pembelahan sel serta metabolisme karbon dan nitrogen.

Tanaman memiliki respons berbeda terhadap kondisi cekaman kekeringan. Salah satu respons tanaman pada kondisi cekaman kekeringan pada berbagai tanaman memperlihatkan adanya peningkatan prolin. Pada kondisi cekaman kekeringan pada berbagai tanaman memperlihatkan terjadinya peningkatan prolin. Sementara prolin merupakan bahan dasar dari terbentuknya 2-acetyl-1-pyrrolin. Oleh karena itu penelitian ini penting dilakukan untuk mengetahui respons padi gogo terhadap pertumbuhan, hasil dan, kandungan prolin dan 2-acetyl-1-pyrrolin biji, sehingga dapat diketahui varietas yang memiliki potensi toleran kekeringan, dengan pertumbuhan dan hasil tinggi.

\section{Bahan dan Metode}

Penelitian dilaksanakan dirumah plastik Universitas Tidar Magelang, pada ketinggian tempat $360 \mathrm{~m}$ dpl. Penelitian dilaksanakan pada bulan September 2012 sampai dengan bulan Maret 2013. Penelitian ini menggunakan
Rancangan Acak Kelompok Lengkap pola faktorial yang diulang 3 kali, masing-masing perlakuan terdiri atas 5 polibag. Faktor pertama varietas padi gogo yang terdiri atas Inpago Unsoed-1, galur JSPGA 136, varietas Situbagendit (non-aromatik) dan varietas Mentik Wangi. Faktor kedua tingkat kadar air tanah yang terdiri atas kadar air tanah $100 \%$ kapasitas lapang dan kadar air tanah $50 \%$ kapasitas lapang. Variabel yang diamati antara lain tinggi tanaman, jumlah anakan total per rumpun, jumlah anakan produktif, total panjang akar, umur berbunga, umur panen, panjang malai, jumlah bulir per malai, bobot 1000 biji, bobot biji per rumpun, kandungan prolin dan kandungan 2-acetyl-1-pirroline.

Analisis data dilakukan dengan menggunakan uji varian dan apabila berbeda nyata dilanjutkan dengan uji Duncan's Multiple Range Test (DMRT) pada tingkat kepercayaan $95 \%$.

\section{Hasil dan Pembahasan}

Berdasarkan hasil analisis ragam Tabel 1 respons padi gogo pada kadar air tanah terhadap pertumbuhan, hasil dan kandungan 2-acetyl-1pyrroline biji menunjukkan bahwa varietas memberikan perbedaan yang sangat nyata pada variabel pengamatan (tinggi tanaman, umur berbunga, umur panen, bobot 1000 biji, bobot biji perumpun, kandungan prolin, dan kandungan 2-acetyl-1-pyrroline) dan berbeda nyata pada variabel jumlah anakan total, jumlah anakan produktif, total panjang akar, panjang malai dan jumlah bulir per malai.

Perlakuan kadar air tanah memberikan perbedaan yang sangat nyata terhadap variabel tinggi tanaman, umur berbunga, umur panen, panjang malai, jumlah bulir per malai, bobot biji per rumpun, dan kandungan 2-acetyl-1-pyrroline, sedangkan pada variabel kandungan prolin hanya memberikan perbedaan yang nyata. Perlakuan kadar air tanah tidak berbeda nyata terhadap variabel jumlah anakan total, jumlah anakan produktif, total panjang akar dan bobot 1000 biji. Terdapat interaksi antara varietas dengan kadar air tanah yaitu pada variabel umur panen dan kandungan 2-acetyl-1-pyrroline.

Tabel 3 menunjukkan bahwa terjadi peningkatan umur panen seiring dengan menurunnya kadar air dari $100 \%$ kapasitas lapang menjadi 50 \% kapasitas lapang. Dari seluruh kombinasi percobaan ternyata varietas Mentik Wangi pada kondisi kadar air tanah $50 \%$ 
memiliki umur panen terpanjang yaitu 159,33 hari dan umur terpendek terdapat pada varietas Situbagendit pada kadar air tanah $100 \%$ kapasitas lapang yaitu 108 hari.

Tabel 4 menunjukkan bahwa varietas Inpago Unsoed-1, galur JSPGA 136 dan Mentik Wangi memperlihatkan peningkatan kandungan 2-acetyl-1-pyrroline, dari kadar air tanah $100 \%$ kapasitas lapang menjadi 50 \% kapasitas lapang. Sementara itu varietas Situbagendit memiliki kandungan 2-acetyl-1-pyrroline yang sama antara kadar air tanah $100 \%$ kapasitas lapang dan 50 kapasitas lapang. Pola peningkatan kandungan 2-acetyl-1-pyrroline terlihat sama antara pada kadar air tanah $100 \%$ kapasitas lapang dan $50 \%$ kapasitas lapang. Semua varietas menunjukkan peningkatan kandungan 2-acetyl-1-pyrroline.

Antar varietas Inpago Unsoed-1, galur JSPGA 136, Situbagendit dan Mentik Wangi memperlihatkan penampilan yang berbeda pada sifat tinggi tanaman, jumlah anakan total, jumlah anakan produktif, umur berbunga, umur panen, panjang malai, jumlah bulir per malai, bobot 1000 biji, bobot biji per rumpun, kandungan prolin dan kandungan 2-acetyl-1pyrroline biji. Secara genetik keempat varietas tersebut memang berbeda sehingga menampilkan ekspresi sifat yang berbeda juga. Namun demikian tidak berarti bahwa apabila varietas yang berbeda tersebut belum tentu dalam sifat tertentu menunjukkan sifat yang sama. Hal ini ditunjukkan untuk sifat panjang akar tanaman.

Inpago Unsoed-1 dan galur JSPGA 136 memperlihatkan penampilan vege-tatif untuk sifat tinggi tanaman, anakan total, anakan produktif, umur berbunga lebih rendah dibandingkan dengan Mentik Wangi. Demikian pula untuk sifat komponen hasil (panjang malai,

Tabel 1. Analisis Ragam terhadap Berbagai Variabel Pengamatan pada Empat Varietas Padi Gogo pada Kadar Air Tanah Berbeda.

\begin{tabular}{lccc}
\hline \hline Variabel Pengamatan & $\mathrm{V}$ & $\mathrm{J}$ & $\mathrm{V} \times \mathrm{J}$ \\
\hline Tinggi Tanaman (cm) & $* *$ & $* *$ & $\mathrm{~ns}$ \\
Jumlah Anakan Total (batang) & $*$ & $\mathrm{~ns}$ & $\mathrm{~ns}$ \\
Jumlah Anakan Produktif (batang) & $*$ & $\mathrm{~ns}$ & $\mathrm{~ns}$ \\
Total panjang Akar (m) & $*$ & $\mathrm{~ns}$ & $\mathrm{~ns}$ \\
Umur Berbunga (hst) & $* *$ & $* *$ & $\mathrm{~ns}$ \\
Umur Panen (hst) & $* *$ & $* *$ & $*$ \\
Panjang Malai (cm) & $*$ & $* *$ & $\mathrm{~ns}$ \\
Jumlah Bulir per Malai & $*$ & $* *$ & $\mathrm{~ns}$ \\
Bobot 1000 Biji (g) & $* *$ & $\mathrm{~ns}$ & $\mathrm{~ns}$ \\
Bobot Biji per Rumpun (g) & $* *$ & $* *$ & $\mathrm{~ns}$ \\
Kandungan Prolin $(\mu$ M/g) & $* *$ & $*$ & $\mathrm{~ns}$ \\
Kandungan 2-acetyl-1-pyrroline (ppm) & $* *$ & $* *$ & $* *$ \\
\hline \hline
\end{tabular}

Keterangan: $\mathrm{V}=$ varietas, $\mathrm{J}=$ kadar air tanah, $\mathrm{ns}=$ tidak berbeda nyata, ${ }^{*}=$ berbeda nyata, ** = berbeda sangat nyata

Tabel 2. Karakter Morfologi, Fisiologi, Hasil dan Komponen Hasil Varietas Padi Gogo yang Ditanam pada Kondisi Kadar Air Tanah Berbeda.

\begin{tabular}{|c|c|c|c|c|c|c|c|c|c|c|}
\hline Perlakuan & $\begin{array}{c}\text { Tinggi } \\
\text { Tanaman } \\
(\mathrm{cm})\end{array}$ & $\begin{array}{c}\text { Jumlah } \\
\text { Anakan } \\
\text { Total } \\
\text { (batang) }\end{array}$ & $\begin{array}{l}\text { Jumlah } \\
\text { Anakan } \\
\text { Produk- } \\
\text { tif } \\
\text { (batang) }\end{array}$ & $\begin{array}{c}\text { Total } \\
\text { Panjang } \\
\text { Akar }(\mathrm{m})\end{array}$ & $\begin{array}{c}\text { Umur } \\
\text { Berbunga } \\
\text { (hst) }\end{array}$ & $\begin{array}{c}\text { Panjang } \\
\text { Malai } \\
(\mathrm{cm})\end{array}$ & $\begin{array}{c}\text { Jumlah } \\
\text { Bulir/mal } \\
\text { ai }\end{array}$ & $\begin{array}{c}\text { Bobot } \\
1000 \text { biji } \\
\text { (g) }\end{array}$ & $\begin{array}{c}\text { Bobot } \\
\text { biji/rump } \\
\text { un (g) }\end{array}$ & $\begin{array}{c}\text { Prolin ( } \\
\mu \\
\mathrm{M} / \mathrm{g})\end{array}$ \\
\hline \multicolumn{11}{|l|}{ Varietas: } \\
\hline Inpago Unsoed-1 & $126,17 \mathrm{~b}$ & $34,33 \mathrm{~b}$ & $29,83 a b$ & $61,62 \mathrm{a}$ & $90,33 \mathrm{~b}$ & $17,00 \mathrm{ab}$ & $95,00 \mathrm{ab}$ & $23,78 \mathrm{a}$ & $32,42 \mathrm{~b}$ & $5,93 \mathrm{c}$ \\
\hline Galur JSPGA 136 & $118,67 \mathrm{c}$ & $30,67 \mathrm{~b}$ & $26,17 \mathrm{~b}$ & $54,96 \mathrm{ab}$ & $89,33 \mathrm{~b}$ & $15,00 \mathrm{~b}$ & $91,12 b$ & $23,43 \mathrm{a}$ & $30,76 \mathrm{~b}$ & $4,12 \mathrm{~d}$ \\
\hline Situbagendit & $99,5 \mathrm{~d}$ & $40,50 \mathrm{a}$ & $33,50 \mathrm{a}$ & $48,38 \mathrm{~b}$ & $77,83 \mathrm{c}$ & $17,17 \mathrm{ab}$ & $87,83 b$ & $20,28 \mathrm{~b}$ & $33,10 \mathrm{~b}$ & $8,02 \mathrm{~b}$ \\
\hline Mentik Wangi & 155 a & $40,50 \mathrm{a}$ & $31,83 \mathrm{a}$ & $51,57 \mathrm{ab}$ & $125,17 \mathrm{a}$ & $18,00 \mathrm{a}$ & $103 \mathrm{a}$ & $20,05 \mathrm{~b}$ & $55,49 \mathrm{a}$ & $19,38 \mathrm{a}$ \\
\hline \multicolumn{11}{|l|}{ KK (\%) } \\
\hline \multicolumn{11}{|l|}{ Kadar air tanah: } \\
\hline $100 \%$ kapasitas lapang & 129,5 a & 34,67 & 30,08 & 55,36 & $92,75 \mathrm{~b}$ & 18,50 a & 101,08 a & 22,27 & $43,95 \mathrm{a}$ & $8,54 \mathrm{~b}$ \\
\hline $50 \%$ kapasitas lapang & $120,17 \mathrm{~b}$ & 38,33 & 30,58 & 52,90 & $98,58 \mathrm{a}$ & $15,08 \mathrm{~b}$ & $87,42 \mathrm{~b}$ & 21,50 & $31,94 \mathrm{~b}$ & $10,19 \mathrm{a}$ \\
\hline KK $(\%)$ & 4,67 & 12,52 & 11,94 & 18,14 & 2,61 & 10,01 & 9,11 & 7,55 & 14,23 & 11,37 \\
\hline
\end{tabular}

Keterangan: Angka yang diikuti huruf yang sama dalam kolom dan perlakuan yang sama menunjukkan antar perlakuan tidak berbeda nyata pada uji DMRT pada tingkat kepercayaan $95 \%$ 
Tabel 3. Pengaruh Interaksi antara Varietas dan Kadar Air Tanah terhadap Umur Panen .

\begin{tabular}{|c|c|c|c|c|}
\hline \multirow{2}{*}{ Varietas } & \multicolumn{4}{|c|}{ Kadar air tanah } \\
\hline & \multicolumn{2}{|c|}{$100 \% \mathrm{KL}$} & \multicolumn{2}{|c|}{$50 \% \mathrm{KL}$} \\
\hline Inpago Unsoed-1 & $\begin{array}{c}127,00 \mathrm{~b} \\
\mathrm{~B}\end{array}$ & (de) & $\begin{array}{c}131,33 \mathrm{~b} \\
\mathrm{~A}\end{array}$ & (c) \\
\hline Galur JSPGA 136 & $\begin{array}{c}124,66 \mathrm{~b} \\
\mathrm{~B}\end{array}$ & (e) & $\begin{array}{c}130,00 \mathrm{~b} \\
\mathrm{~A}\end{array}$ & (cd) \\
\hline Situbagendit & $\begin{array}{c}108,00 \mathrm{c} \\
\mathrm{B}\end{array}$ & (g) & $\begin{array}{c}114,00 \mathrm{c} \\
\mathrm{A}\end{array}$ & (f) \\
\hline Mentik Wangi & $\begin{array}{c}148,00 \text { a } \\
\text { B }\end{array}$ & (b) & $\begin{array}{c}159,33 \text { a } \\
\text { A }\end{array}$ & (a) \\
\hline
\end{tabular}

\section{Keterangan:}

1. Angka-angka yang diikuti huruf non kapital yang sama pada kolom yang sama (kadar air tanah) menunjukkan tidak berbeda nyata pada uji DMRT pada tingkat kepercayaan $95 \%$

2. Angka-angka yang diikuti huruf kapital yang sama pada baris yang sama (varietas) menunjukkan tidak berbeda nyata pada uji DMRT pada tingkat kepercayaan $95 \%$

3. Angka-angka yang diikuti huruf non kapital yang sama di dalam tanda kurung menunjukkan tidak berbeda nyata pada uji DMRT pada tingkat kepercayaan $95 \%$.

Tabel 4. Pengaruh Interaksi Antara Varietas dengan Kadar Air Tanah terhadap Kandungan 2-Acetyl-1-Pyrroline.

\begin{tabular}{|c|c|c|c|c|}
\hline \multirow{2}{*}{ Varietas } & \multicolumn{4}{|c|}{ Kadar air tanah } \\
\hline & \multicolumn{2}{|c|}{$100 \% \mathrm{KL}$} & \multicolumn{2}{|c|}{$50 \% \mathrm{KL}$} \\
\hline Inpago Unsoed-1 & $\begin{array}{c}0,022 \mathrm{~b} \\
\mathrm{~B}\end{array}$ & (d) & $\begin{array}{c}0,049 \mathrm{~b} \\
\mathrm{~A}\end{array}$ & (c) \\
\hline Galur JSPGA 136 & $\begin{array}{c}0,014 \mathrm{~b} \\
\mathrm{~B}\end{array}$ & (de) & $\begin{array}{c}0,044 \mathrm{~b} \\
\mathrm{~A}\end{array}$ & (c) \\
\hline Situbagendit & $\begin{array}{c}0,002 \mathrm{c} \\
\mathrm{A}\end{array}$ & (f) & $\begin{array}{c}0,007 \mathrm{c} \\
\mathrm{A}\end{array}$ & (ef) \\
\hline Mentik Wangi & $\begin{array}{c}0,092 \mathrm{a} \\
\mathrm{B}\end{array}$ & (b) & $\begin{array}{c}0,189 \text { a } \\
\text { A }\end{array}$ & (a) \\
\hline
\end{tabular}

\section{Keterangan:}

1. Angka-angka yang diikuti huruf non kapital yang sama pada kolom yang sama (kadar air tanah) menunjukkkan tidak berbeda nyata pada uji DMRT pada tingkat kepercayaan $95 \%$

2. Angka-angka yang diikuti huruf kapital yang sama pada baris yang sama (varietas) menunjukkkan tidak berbeda nyata pada uji DMRT pada tingkat kepercayaan $95 \%$

3. Angka-angka yang diikuti huruf non kapital yang sama di dalam tanda kurung menunjukkan tidak berbeda nyata pada uji DMRT pada tingkat kepercayaan $95 \%$.

jumlah bulir per malai,) lebih rendah dibanding Mentik Wangi. Hal ini menyebabkan kedua varietas tersebut juga hasilnya (bobot biji per rumpun) lebih rendah dibanding Mentik Wangi. Hal ini pula sejalan dengan yang terjadi pada varietas Situbagendit yang memiliki hasil yang sama dengan Inpago Unsoed-1 dan galur JSPGA 136.

Tinggi tanaman merupakan salah satu indikator pertumbuhan tanaman yang mudah dilihat (Sitompul dan Guritno, 1995). Tinggi tanaman dan jumlah anakan total pada varietas Situbagendit menunjukkan hasil yang bertolak belakang (Tabel 2). Semakin banyak jumlah anakan total maka jumlah anakan produktif akan semakin banyak dan tinggi tanaman semakin rendah, begitu juga panjang akar tanaman semakin rendah, hal ini diduga karena fotosintat yang dihasilkan tanaman akan didistribusikan ke seluruh bagian organ sehingga apabila distribusi-nya banyak ke pembentukan anakan akan diikuti dengan rendahnya tinggi tanam-an, begitu juga sebaliknya. Umur berbunga pada varietas Situbagendit lebih cepat dibandingkan dengan varietas lainnya, hal ini dikarenakan faktor genetik tanaman..

Mentik Wangi memiliki malai yang lebih panjang dibandingkan dengan varietas lainnya. Panjang malai merupakan salah satu komponen produksi. Hal ini akan menghasilkan jumlah 
bulir per malai lebih banyak dan menghasilkan bobot biji per rumpun tertinggi. Setiap Varietas memiliki karakteristik tertentu dalam hal sifatnya. Mentik Wangi memiliki sifat tersebut sehingga hasilnya lebih tinggi dibandingkan dengan varietas lain yang diuji.

Kandungan prolin tertinggi dihasilkan pada varietas Mentik Wangi sehing-ga menghasilkan kandungan 2-acetyl-1- pyrroline yang tinggi juga karena Mentik Wangi merupakan padi aromatik, dimana aroma padi disebabkan oleh senyawa kimia yang mudah menguap. Aroma padi dipengaruhi oleh faktor lingkungan dan genetik. Berdasarkan hasil penelitian Buttery et al. (1983), 2-acetyl-1-pyrroline adalah senyawa kimia utama penyebab keharuman aroma pada daun pandan. Yoshihashi et al. (2002) mengemukakan bahwa prekursor dan sumber nitrogen 2-acetyl-1-pyrroline pada varietas aromatik Thai Hom Mali adalah senyawa prolin. Mentik Wangi memberikan indikasi bahwa varietas tersebut toleran terhadap cekaman kekeringan.

Tanaman yang ditanam pada kondisi kadar air tanah $100 \%$ kapasitas lapang menghasilkan tinggi tanaman lebih tinggi, umur berbunga lebih cepat, panjang malai lebih panjang, jumlah bulir per malai lebih banyak dibandingkan dengan tanaman yang ditanam pada kondisi kadar air tanah $50 \%$ kapasitas lapang. Hal ini dikarenakan dengan pemberian air sesuai dengan kebutuhan tanaman menyebabkan proses pertumbuhan tanaman berjalan dengan baik. Dengan jumlah bulir per malai lebih banyak maka bobot biji per rumpun akan lebih besar. Respons tanaman dalam menghadapi cekaman kekeringan salah satunya adalah dengan meningkatkan jumlah prolin daun. Peran asam amino prolin adalah untuk mengatur tekanan osmotik sel tanaman sebagai upaya bertahan terhadap kondisi yang tidak menguntungkan, seperti pernyataan Ronde et al. (2000) yaitu semakin menurunnya kandungan air dalam tanah akan menyebabkan tanaman menginduksi prolin untuk menjaga tekanan turgor sel. Hal ini didukung pula dengan pernyataan Heldt (2005) yang menyatakan bahwa prolin berfungsi sebagai zat pelindung terhadap kerusakan daun ketika terjadi dehidrasi.

Menurut Sharp (2002), beberapa penelitian menunjukkan bahwa ketahanan terhadap cekaman kekeringan berhubungan dengan peningkatan kandungan prolin yang berperan penting dalam menjaga pertumbuhan akar pada potensial osmotik air yang rendah. Begitu pula, Hamim et al. (1996) dan Naiola (1996) juga mengatakan hal yang senada, yaitu penurunan potensi osmosis, merupakan respons tanaman yang baik untuk bertahan terhadap cekaman kekeringan dengan mengakumulasikan senyawa-senyawa terlarut untuk penyesuaian potensi osmosis sehingga sel-sel tanaman tetap mampu mempertahankan turgornya.

Akumulasi prolin berkontribusi pada kemampuan tanaman untuk memper-tahankan diri pada kondisi stres kekeringan (Taylor, 1996). Kemampuan masing-masing tanaman ini menyebabkan respons beragam yang diakibatkan oleh ceka-man kekeringan. Akumulasi jumlah prolin dianggap merupakan indikasi toleransi pada kondisi cekaman kekeringan karena prolin berfungsi sebagai senyawa penyimpan $\mathrm{N}$ dan osmoregulator dan atau sebagai protektor enzim tertentu (Yoshiba et al., 1997).

Hasil penelitian Buttery et al. (1983) memperlihatkan bahwa prolin merupakan senyawa dasar pembentukan 2-acetyl-1-pyrroline. Semakin tinggi prolin yang dihasilkan oleh tanaman maka kandungan 2-acetyl-1-pyrroline juga akan semakin tinggi. Dengan meningkatnya 2-acetyl1-pyrroline akan menyebab-kan aromatik beras semakin tinggi. Namun beberapa hasil penelitian memperlihat-kan bahwa senyawa 2-acetyl1-pyrroline tidak stabil sehingga beras aromatik yang disimpan dalam periode yang cukup lama kadar aromatiknya akan ber-kurang.

Hasil penelitian ini memperlihatkan pula bahwa terjadi interaksi antara kadar air tanah (cekaman kekeringan) dan varietas untuk variabel kandungan 2-acetyl-1-pyrroline. Hal ini menunjukkan bahwa varietas Mentik Wangi baik pada kondisi kadar air tanah $100 \%$ kapasitas lapang maupun pada kondisi kadar air tanah $50 \%$ kapasitas lapang mengandung 2acetyl-1-pyrroline lebih tinggi diban-ding dengan varietas Inpago Unsoed-1, galur JSPGA 136 dan varietas Situba-gendit. Hal ini memperlihatkan bahwa varietas Mentik Wangi lebih memiliki aroma yang kuat dibandingkan dengan varietas Situbagendit, galur JSPGA 136 dan varietas Inpago Unsoed-1. Senyawa 2-acetyl-1-pyrroline merupakan senyawa tidak stabil keberadaannya pada padi. Hal ini terasa bau aroma pada padi yang telah disimpan lama jauh berkurang. Menurut Yoshihashi et al. (2005), kandungan 2Acetyl-1-pyrolline dipengaruhi oleh derajat penggilingan, waktu dan suhu penyimpanan. Kandungan 2-Acetyl-1-pyrroline dalam beras aromatik selama penyimpanan menurun lebih cepat dengan semakin meningkatnya suhu 
penyimpanan. Setiap varietas yang diuji kandungan 2-acetyl-1-pyrroline nya meningkat sejalan dengan menurunnya kadar air tanah dan setiap varietas memberikan respons yang berbeda. Peningkatan kandungan 2-acetyl-1-pyrroline akibat penurunan kadar air tanah dan sangat tergantung pada varietas yang digunakan.

\section{Kesimpulan}

1. Tanaman padi gogo yang ditanam pada kondisi kadar air tanah $50 \%$ kapasitas lapang menghasilkan tinggi tanaman rendah (120,17 cm), umur berbunga (125,17 hari) dan umur panen lebih lama (159,3 hari) malai yang pendek $(15,08 \mathrm{~cm})$, jumlah bulir per malai sedikit $(87,42)$ dan bobot biji per rumpun rendah $(31,94 \mathrm{~g})$ tetapi kandungan prolin dan kandungan 2-acetyl-1-pyrroline lebih tinggi dibandingkan dengan yang ditanam pada kondisi kadar air tanah $100 \%$ kapasitas lapang.

2. Varietas Mentik Wangi memiliki kandungan 2-acetyl-1-pyrroline paling tinggi pada kondisi kadar air tanah $50 \%$ kapasitas lapang, yang didukung dengan jumlah anakan produktif banyak, malai yang panjang, jumlah bulir per malai lebih banyak, bobot biji per rumpun dan kandungan prolin tinggi, namun memiliki umur berbunga dan umur panen lama.

\section{Daftar Pustaka}

Buttery, R.G., L.C. Ling, B.O. Juliano, and J.G. Turnbaugh. 1983. Cooked rice aroma and 2acetyl-1-pyrroline. J. Agric. Food Chem., 31:823826.

Hamim, A.D., D. Sopandie dan M. Yusuf. 1996. Beberapa Karakteristik Morfologi dan Fisiologi Kedelai Toleran dan Peka terhadap Cekaman Kekeringan. Hayati, 3(1):30-34

Lin, C. F.; Hsieh, T. C.-Y.; Hoff, B. J. 1990. Identification and Quantification of the "Popcorn"-like Aroma in Louisiana Aromatic Della Rice (Oryza sativa, L.). J. Food Science., 55:1466-1469.

Naiola, B. Paul. 1996. Ulas Balik. Regulasi Osmosis pada Tumbuhan Tinggi. Hayati, 3(1):1-6.

Paule, C. M.; Powers, J. J. 1989. Sensory and Chemical Examination of Aromatic and Nonaromatic Rices. J. Food Sci., 54:343-346.

Ronde, J.A., Mescht, V.D., Steyn, H.F.S. 2000. Proline Accumulation in Response to drought and heat stress in cotton. African Crop Science Journal, 8(1):85-91.

Salisbury, F.B., C.W. Ross. 1995. Plant Physiology. $4^{\text {th }}$ edition. Wadsworth Pub.Co.747 p.

Sanzhez, F.J., M. Manzanares, E.F. de Andres, J.L. Tenorio, L. Ayerbe. 1998. Turgor maintenance, osmotic adjusment and soluble sugar and proline acumullation in 49 pea cultivars in respon to water stress. Field Crop Res., 59: 225-235.

Sharp, R.E. 2002. Interaction with ethylene: changing views on the role of abscisic acid in root and shoot growth responses to water stress. Plant, Cell and Environment J. 25: 211-222

Sitompul, M. dan B. Guritno. 1995. Analisis Pertumbuhan Tanaman. Gadjah Mada University Press. Yogyakarta.

Sood, B.C., and E.A. Siddiq. 1980. Studies on Component Quality Attributes of Basmati rice, Oryza sativa L. Dalam Totok, A.D.H. 2008. Mutiara yang Terlupakan (Upaya Peningkatan Ketahanan Pangan Melalui Pengembangan Padi Gogo Aromatik). Orasi Ilmiah Pengukuhan Guru Besar. Diakses dari:http:/ / pascaunsoed.files.wordpress.co m/2008/04/orasi-ilmiah-guru-besar-totokagung.pdf

Totok. A.D.H. 2008. Mutiara yang Terlupakan (Upaya Peningkatan Ketahanan Pangan Melalui Pengembangan Padi Gogo Aromatik). Orasi Ilmiah. 58 h. Diakses dari: http:// pascaunsoed.files.wordpress.com/2008/04/o rasi-ilmiah-guru-besar-totok-agung.pdf

Yamada, Y. 1984. Plant Nutrition Under Water Stress Condition. Pp.367-381. Dalam Prichananda and Yungchol, P. (eds.) Ecology and Management of Problem Soils in Asia. Food and fertilizer Technology Center for the Asian and Facific Region. Taiwan.

Yoshiba, T. Kiyosue, K. Nakashima, K. Yamaguchi, Shinozaki and K. Shinozaki, 1997. Regulation of levels of proline as an osmolyte in plants under waterstress. Plant Cell Physiology 38 (10):1095 - 1102.

Yoshihashi, T., Huong, N. T. T., Surojanametakul, V., Tungtrakul, P., Varanyanond, W. 2005. Efeect of Storage Conditions on 2Acetyl-1-pyrroline Content in Aromatic Rice Variety, Khao Dawk Mali 105. Journal of Food Scienc, . 70(1) :S34-S37.

Yuwandha. W. 2008. Prospek Pengembangan Padi Gogo Aromatik Dalam Upaya Menunjang Ketahanan Pangan (Online). http:// cdsindonesia.wordpress.com/2008/03/31/pr ospek-pengembangan-padi-gogo-aromatikdalam-upaya-menunjang-ketahanan-pangan/ 